\title{
K2 SHAFT WATER RING INSTALLATION AT KENCANA UNDERGROUND PT NUSA HALMAHERA MINERAL
}

\author{
Abdi Wahyudi Samad \\ Superintendent Shaft \& UG Project, PT Nusa Halmahera Minerals
}

\begin{abstract}
ABSTRAK
Kencana 2 (K2) Shaft sebagai salah satu jalur lubang terbuka vertikal pada fasilitas Kencana UG PTNHM terdapat rembesan air 8 1/s melalui kontak sambungan (cold joint) antara dinding concrete shaft pada beberapa level. Air tersebut membasahi jalur winder cage dan tali pengaman dari winder shaft dan berakibat masalah korosif menyebabkan terganggu jalur evakuasi yang berpotensi terjadi gangguan produksi jika tidak di atasi. Pengusulan pemasangan talang air khusus pada dinding shaft terhubung langsung pada pipa services DN150 yang terpasang sepanjang $284 \mathrm{~m}$ menuruni dinding shaft. Talang air khusus ini terbuat dari material galvanis yang kuat dan tahan lama. Pipa services DN150 terhubung langsung menuju stasiun \#3 pompa KL. Dari hasil pengamatan setelah terpasang talang air khusus ini, tidak terjadi lagi rembesan air yang masuk kedalam ruangan winder cage dan tali winder, serta kondisi rembesan air pada dinding shaft telah dialirkan menuju stasiun pompa KL sehingga area K2 shaft menjadi kering
\end{abstract}

Kata Kunci: Modifikasi Shaft Winder Platform, Pemasangan Talang Air Khusus.

\begin{abstract}
The Kencana 2 (K2) Shaft as a vertical open hole UG facility at Kencana UG PTNHM has approximately $8 \mathrm{l} / \mathrm{s}$ inflow of water leaking through the cold joints in the concrete liner at various locations. This water saturates the winder cage room and the guide ropes in the winder of shaft and has caused corrosion issues causing the escape route to be compromised leading to a production loss if not take prevention action. It was proposed to install a prefabricated moulded water ring on the wall of the shaft to direct water to a DN150 services steel pipe line that runs down to a $284 m$ depth down of the shaft wall. This water ring using galvanised material and it is tough and durable. The services pipe DN150 would then be piped away from bottom of the K2 shaft to a nearby KL pump station \#3. From observation result after water ring installed that there was no water rain into winder cage and rope, and it also the dripping down of the water along the shaft concrete wall was divert throught to the KL pump station so that the K2 shaft area was getting dry.
\end{abstract}

Key Word: Modification Shaft Winder Platform, Water Ring Installation.

\section{A. PENDAHULUAN}

\section{A.1. Latar Belakang}

Gosowong mine site PT Nusa Halmahera Minerals berlokasi di pulau Halmahera propinsi Maluku Utara, dan terdapat dua tambang bawah tanah aktif yaitu Kencana UG (mulai 2007) dan Toguraci UG (mulai 2011), sebelumnya sudah ada dua tambang terbuka yang telah selesai berproduksi yaitu Gosowong Open Pit dan Toguraci Open Pit. Metode tambang bawah tanah yang digunakan pada Kencana UG adalah Underhand Cut and Fill, sedangkan Toguraci UG menerapkan metode Stoping untuk kegiatan produksi dengan sistim ekstrasi drilling and blasting. 
Salah satu fasilitas UG yang menunjang kegiatan penambangan di Kencana UG adalah Kencana 2 (K2) Shaft merupakan jalur lubang terbuka vertikal dibuat pada tahun 2010 yang berfungsi sangat vital sebagai jalur ventilasi (intake / jalur udara masuk dan exhaust / jalur udara keluar) dan jalur keluar darurat (emergency escape way) untuk Kencana UG developmen area. K2 shaft desain dengan diameter $5.5 \mathrm{~m}$ lebar lubang terbuka (open hole) dan $284 \mathrm{~m}$ kedalaman total, dan menggunakan platform shaft serta winder cage sebagai alat angkut naik-turun ke UG. Struktur perkuatan dinding shaft digunakan kombinasi material ground support (bolting-meshing) bagian dalam penyanggaan dan dinding concrete pada bagian luar.

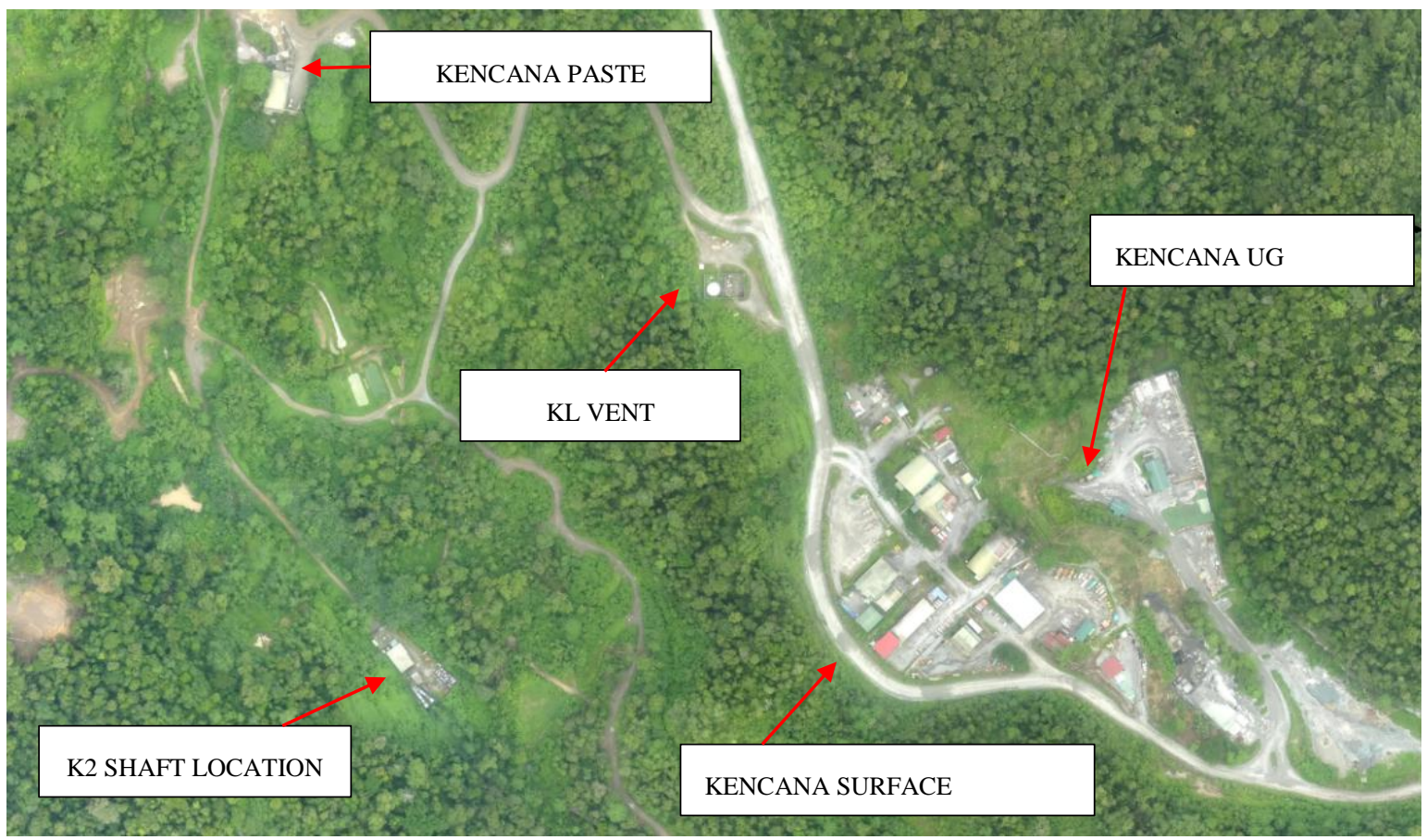

Gambar 1. Kencana UG Fasilitas Permukaan dan UG Portal

\section{1) Local Geology}

Endapan bijih tambang bawah tanah Kencana dan Toguraci termasuk dalam kategori epithermal vein system yang secara umum di dominasi oleh jenis batuan quarts pada badan bijih (ore body) dan beberapa jenis batuan andesite, basalt, dan diorite sebagai penyusun pada batuan sekitar (host rock). Beberapa lokasi area penambangan juga terdapat jalur patahan (fault) yang menjadi tantangan dalam kegiatan penambangan.

\section{2) Site Hydrology}

Gosowong mine site lokasi berada pada jalur reservoir geothermal aktif dimana berada tepat 1-2 $\mathrm{km}$ dibawah tambang. Struktur diorite pada zonasi host rock diinterpretasi sebagai struktur pembawa air bawah tanah. Selain faktor air bawah tanah pada lokasi penempatan K2 shaft, juga pengaruh air permukaan dimana terdapat area alur sungai permukaan yang melalui lubang drill holes exploration yang berada perpotongan pada batuan sekitar lokasi K2 shaft sehingga berpotensi yang memungkinkan terjadi rembesan air pada konstruksi shaft.

\section{3) Konstruksi Shaft}

Konstruksi shaft secara umum terdiri dari shaft headframe, motor hoist, winder cage, dan landing area pada bagian bawah shaft (bottom K2 shaft) yang berada di UG.

Hoisting sistem menggunakan drum hoist tunggal yang terpasang di permukaan pada Winder room control. Winder Cage bisa mengangkut max 10 orang atau $880 \mathrm{~kg}$ untuk pengoperasian naik-turun dengan dipandu oleh 2 tali kawat baja khusus (travel guide steel ropes). Pembagian sekat ruangan untuk K2 shaft dengan komposisi 60:40 dimana luas section jalur udara masuk (Fresh Air Raise FAR) $14,11 \mathrm{~m}^{2}$ dan jalur udara keluar (Return Air Raise - RAR) $9,25 \mathrm{~m}^{2}$. 


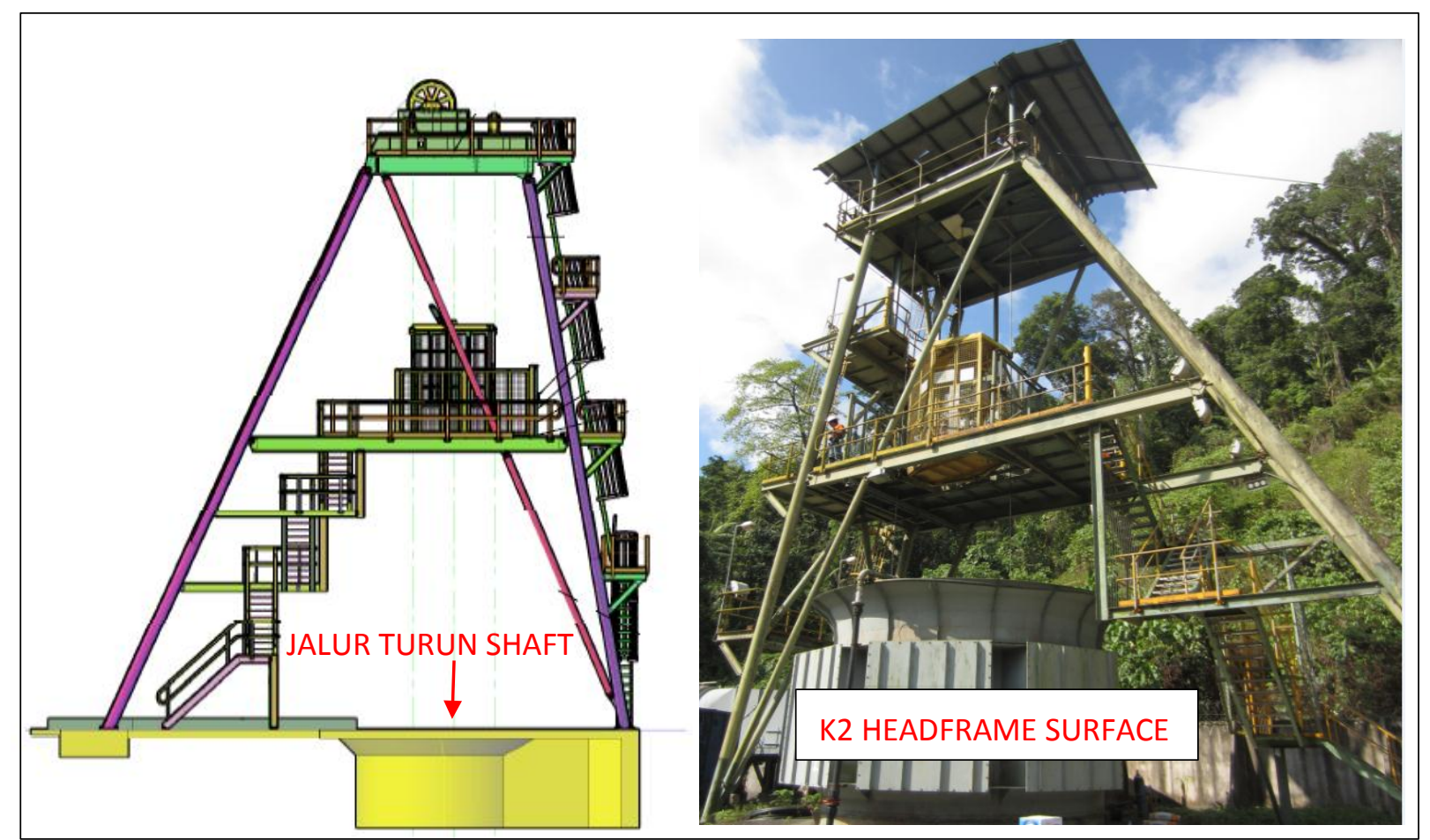

Gambar 2. K2 shaft headframe desain (kiri) dan lokasi K2 shaft headframe permukaan - aktual (kanan)

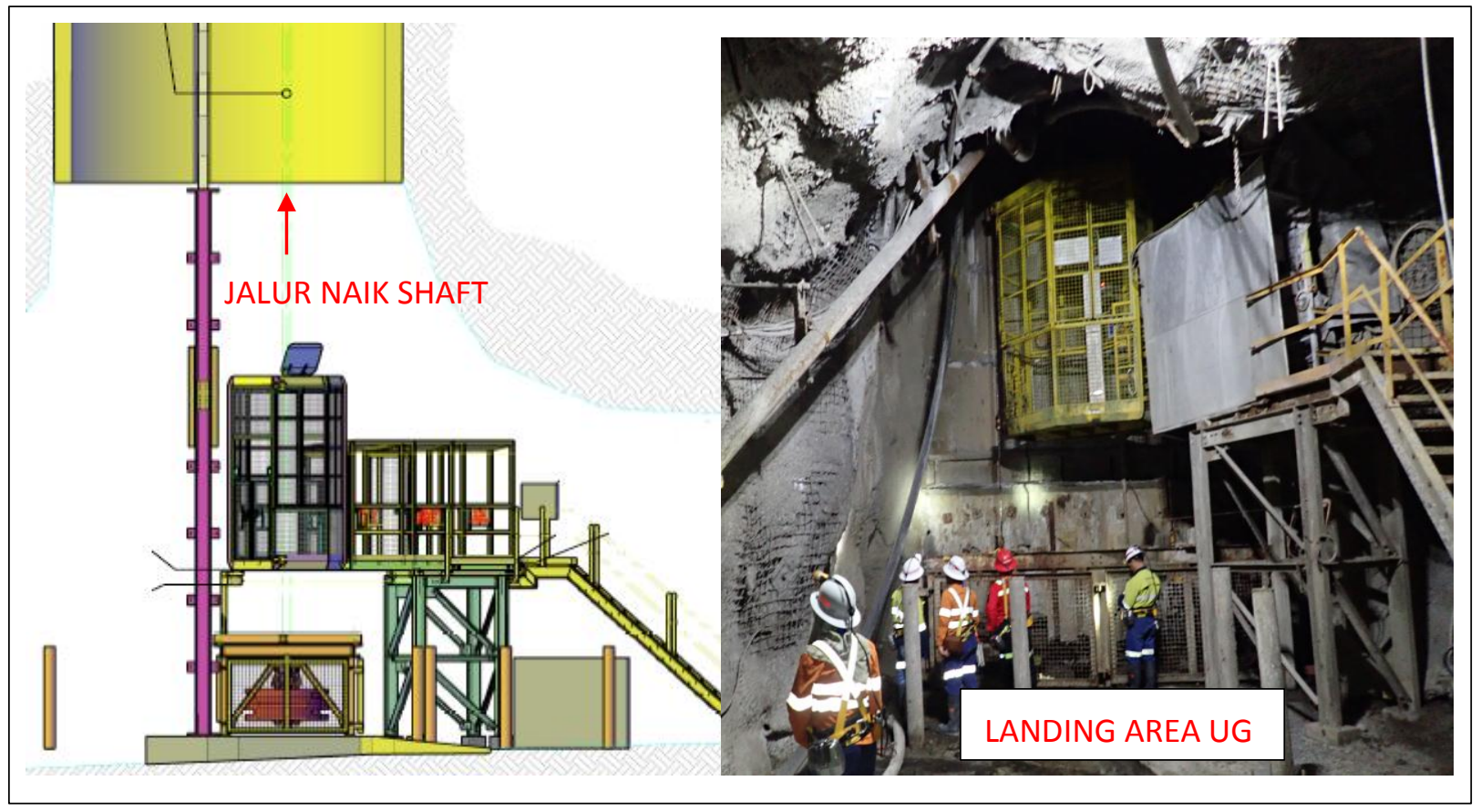

Gambar 3. K2 shaft landing UG area - desain (kiri) dan lokasi landing UG area - aktual (kanan) 


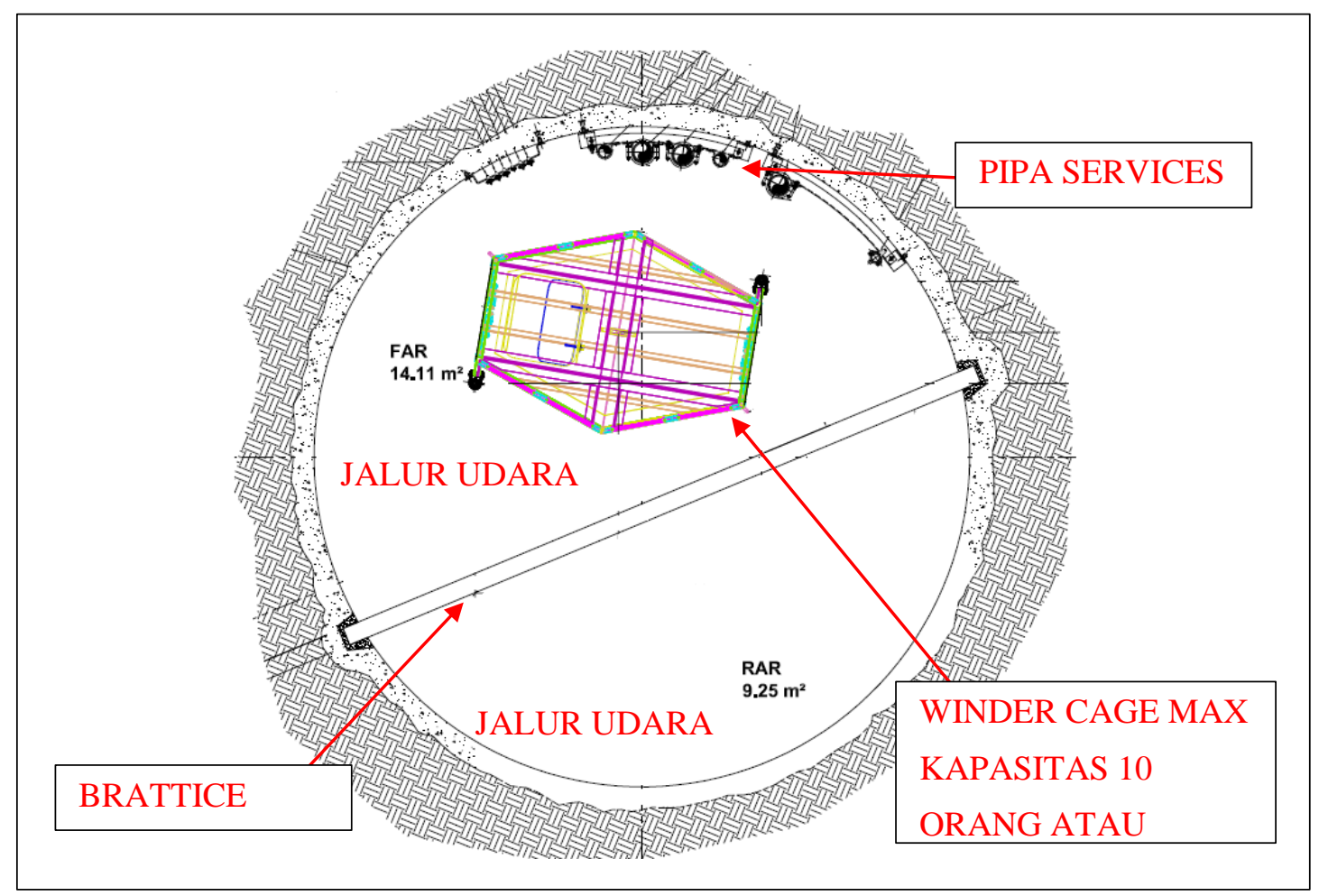

Gambar 4. K2 shaft egress jalur naik - turun dengan winder cage (Tampak Atas)

\section{A.2. Tujuan}

Tujuan dari pemasangan water ring pada K2 Shaft Egress.

- Mengurangi kerusakan konstruksi shaft dan fasilitas winder cage akibat rembesan air.

- Mengantisipasi terbentuknya endapan kalsit pada dinding shaft yang dapat menghalangi jalur evakuasi.

- Implementasi UG Dewatering Management.

\section{A.3. Pendekatan Pemecahan Masalah}

Pengumpulan data dilakukan sebagai langkah awal dalam pemecahan masalah, terutama data area potensial rembesan dan pemetaan kondisi dinding beton shaft (concrete lining). Selanjutnya hasil temuan akan dibahas melalui diskusi/meeting, sharing, dan mencari referensi baik dari internal maupun eksternal. Hal terpenting dalam pemecahan masalah adalah pemilihan jenis water ring dan penentuan metode pengerjaan rehab (work methodology).

\section{B. METODOLOGI PENELITIAN}

- Pengumpulan data lapangan menggunakan visualisasi inspeksi dan pemetaan (mapping).

Hasil laporan pengamatan aktual lapangan diperlukan sehingga UG Department dapat menentukan keputusan waktu pekerjaan rehab di shaft area, karena berhubungan dengan penggunaan akses shaft dalam proses pekerjaan. Pemetaan berdasarkan level kedalaman yang mengalami kerusakan dan membuat deskripsi tingkat kerusakan akibat rembesan pada dinding shaft.

- Penentuan bahan dan jenis water ring.

Water ring atau water gutter atau talang air khusus terdiri dari beberapa bagian yang terpisah dan mempunyai kemampuan dapat bertahan pada kondisi jenuh/basah. Penentuan dimensi ring yang akan dipasang juga sangat penting dalam estimasi kualitas kapasitas tampung untuk pengaliran dan pekerjaan pemasangan water ring. 
- Metode Pengerjaan.

Pembuatan metode pengerjaan rehab (work methodology) berhubungan juga dengan standar pekerjaan yang telah ditentukan berdasarkan site standard, termasuk juga fokus pekerjaan beresiko tinggi (high risk) mengenai bekerja di ketinggian (working at height - WAH) dan bekerja di lubang terbuka (open hole working).

\section{HASIL DAN PEMBAHASAN}

\section{C.1. Cold joint dan Endapan Calcite}

Hasil inspeksi bersama dilapangan, teridentifikasi beberapa sambungan/kontak dinding concrete ("cold joint") yang retakan terbuka (micro crack) akibat dorongan air yang tersingkap dibelakang dinding concrete shaft di beberapa level, hal ini disebabkan oleh adanya perpotongan struktur pembawa air (reservoir structure) serta infiltrasi air permukaan yang masuk melalui lubang bor (bore hole exploration) yang memotong struktur batuan disekitar lokasi K2 Shaft, sehingga menyebabkan adanya rembesan air dan terbentuknya endapan kalsit.

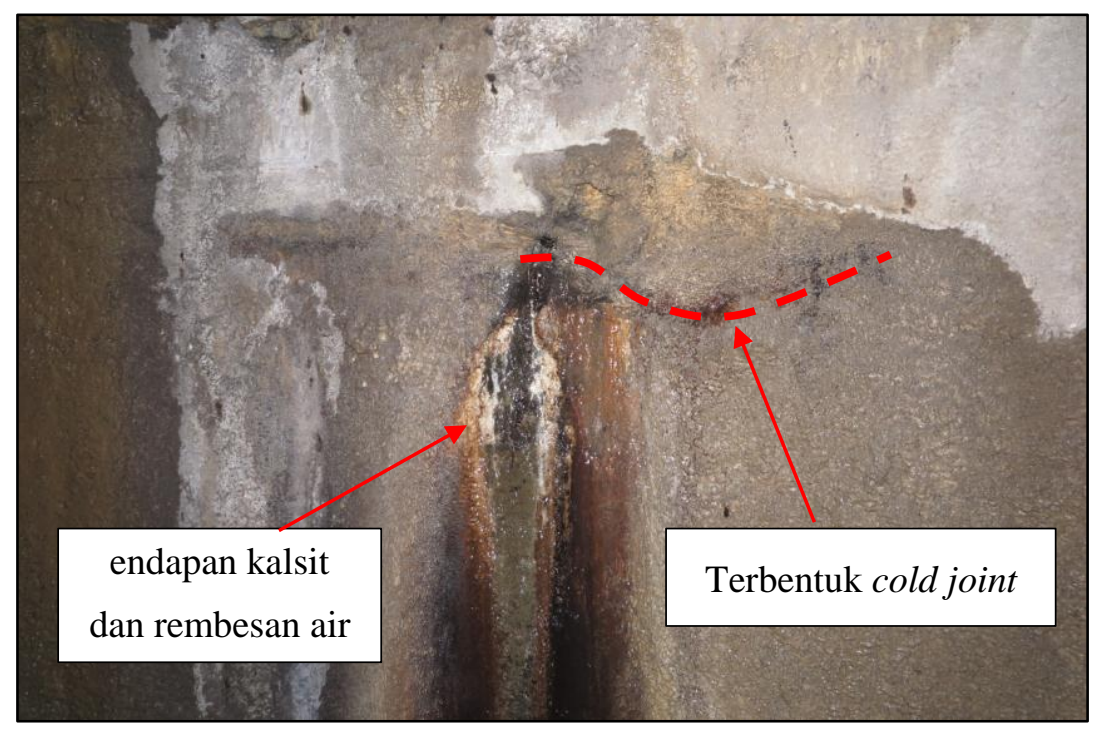

Gambar 5. Identifikasi terbentuknya endapan kalsit, "cold joint", dan spot rembesan air

Tabel 1. K2 shaft egress level lokasi pemasangan water ring

\begin{tabular}{cc}
\hline K2 Shaft Level - m depth & Pemasangan Water Ring \\
\hline 70,0 & Water Ring 1 set (8,8 m panjang) \\
102,5 & Water Ring 1 set (8,8 m panjang) \\
126,4 & Water Ring 1 set (8,8 m panjang) \\
200,0 & Water Ring 1 set (8,8 m panjang) \\
\hline
\end{tabular}

\section{C.2. Pemilihan bahan dan desain Water Ring}

Water ring atau water gutter atau talang air khusus terdiri dari beberapa bagian yang terpisah dan bahan yang akan dipilih harus sesuai dengan kondisi dilapangan terutama pada daerah basah (saturated). Rencana K2 shaft egress pekerjaan rehab diputuskan menggunakan material plat besi yang tahan karat dan dapat fabrikasi sesuai dimensi dan pola melingkar pada dinding shaft. Proses pengerjaan fabrikasi water ring dilakukan di luar shaft (workshop surface) dan dibentuk dalam 4 potongan terpisah dgn ukuran $2,1 \mathrm{~m}$ per ring sehingga mempermudah saat pemasangan. Pemasangan dilakukan didalam shaft. Penentuan dimensi ring yang akan dipasang juga sangat 
penting dalam estimasi kualitas kapasitas tampung untuk pengaliran dan pekerjaan pemasangan water ring.

Tabel 2. Spesifikasi water ring dan dimensi

\begin{tabular}{cc}
\hline Specification Water Ring & Dimension \\
\hline Tipe material & Stainless Steel \\
\hline Ketebalan material & $1,5 \mathrm{~mm}$ \\
\hline Lebar Ring & $100 \mathrm{~mm}$ \\
\hline Tinggi Ring & $102 \mathrm{~mm}$ \\
\hline Lebar Gantungan Dalam Ring & $51 \mathrm{~mm}$ \\
\hline Panjang Section Ring & $2100 \mathrm{~mm}$ \\
\hline
\end{tabular}

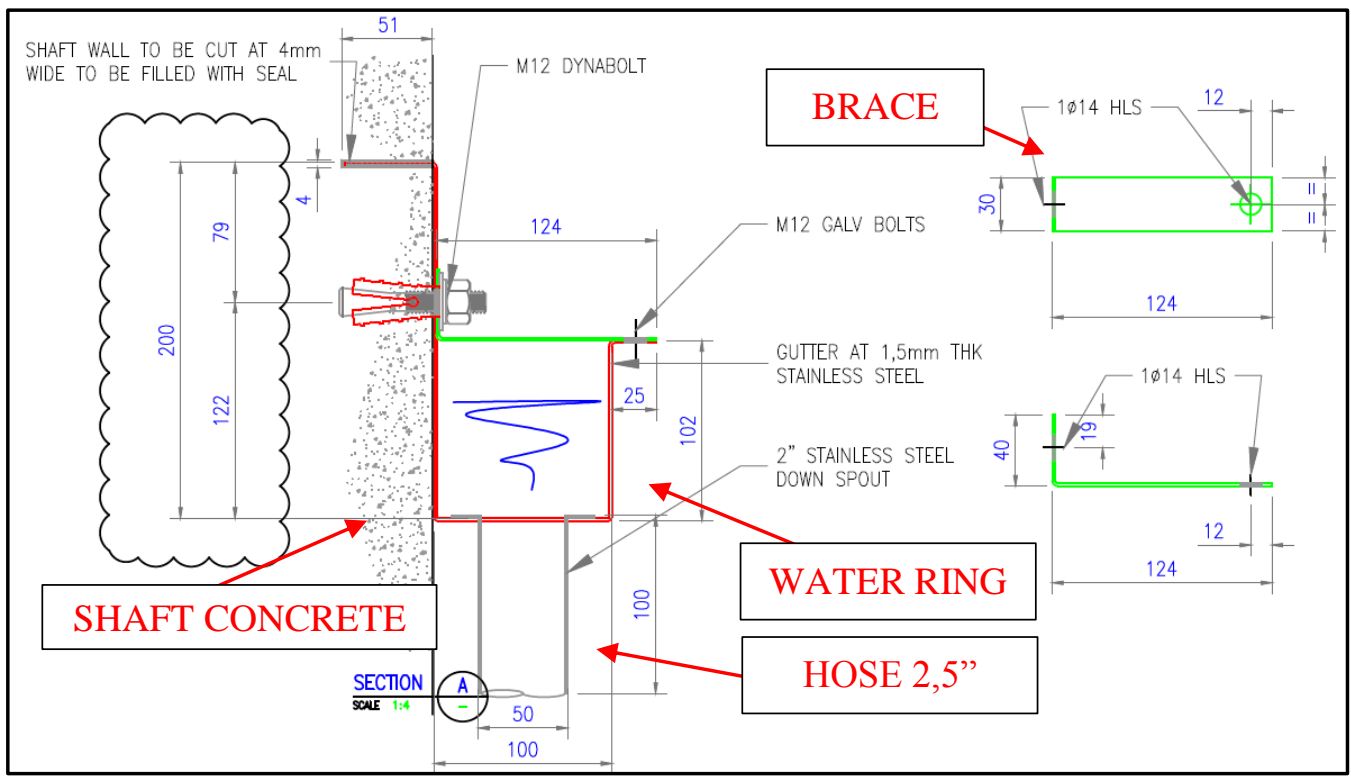

Gambar 6. Dimensi dan desain water ring K2 shaft egress

\section{C.3. Pemasangan Water Ring dan Penyambungan Pipa Air Services}

Pemasangan water ring dilakukan dari level yang paling teratas kemudian menuju spot level bawah menggunakan winder cage. Komunikasi dalam bekerja dengan operator winder sangat penting, mengingat modul penggerak motor winder berada di permukaan. Satu rangkaian water ring bisa terdiri dari 4 rings dimana salah satu sisi ring terpasang lubang pengaliran (drain hole) yang terhubung dengan selang (hose) 2,5" menuju ke pipa service DN150. Setiap ring akan disambungkan dengan cara dijepit dan kunci setiap sisi water ring.

Tahapan pemasangan water ring dan penyambungan pipa air meliputi

- Membersihkan endapan kalsit yang terbentuk pada dinding shaft. Tentukan posisi water ring dengan cara memberikan tanda pada dinding shaft. Potong dinding concrete shaft menggunakan gerinda angin $5 \mathrm{~mm}$ sedalam $51 \mathrm{~mm}$ sebagai alur penjepit water ring. Daerah potongan akan direkatkan dengan lem silikon khusus anti air.

- Pasang water ring per section untuk mengalihkan air masuk ke dalam water ring.

- Masukan dan pasang water ring melewati section pipa services. 
- Pasang pengait (brace) dan baut (bolt) penahan water ring setiap $60 \mathrm{~cm}$. Pakai dyna bolt M12 dan akan bor ke dalam dinding concrete $10 \mathrm{~cm}$. Tarik dan sambung antar pengait setiap ring dan jepit rapat.

- Sambungkan lubang water ring ke selang air 2,5" flexsibel hose membentuk 45 derajat sambungan.

- Potong lubang services air (cutting weld) dan sambungkan drain pipe 2,5" flexsibel hose sekaligus kunci dan kencangkan pipa hose pada dinding dengan memasangan penahan baut. Penggunaan material khusus untuk melapisi antara sambungan pipa dengan hose.
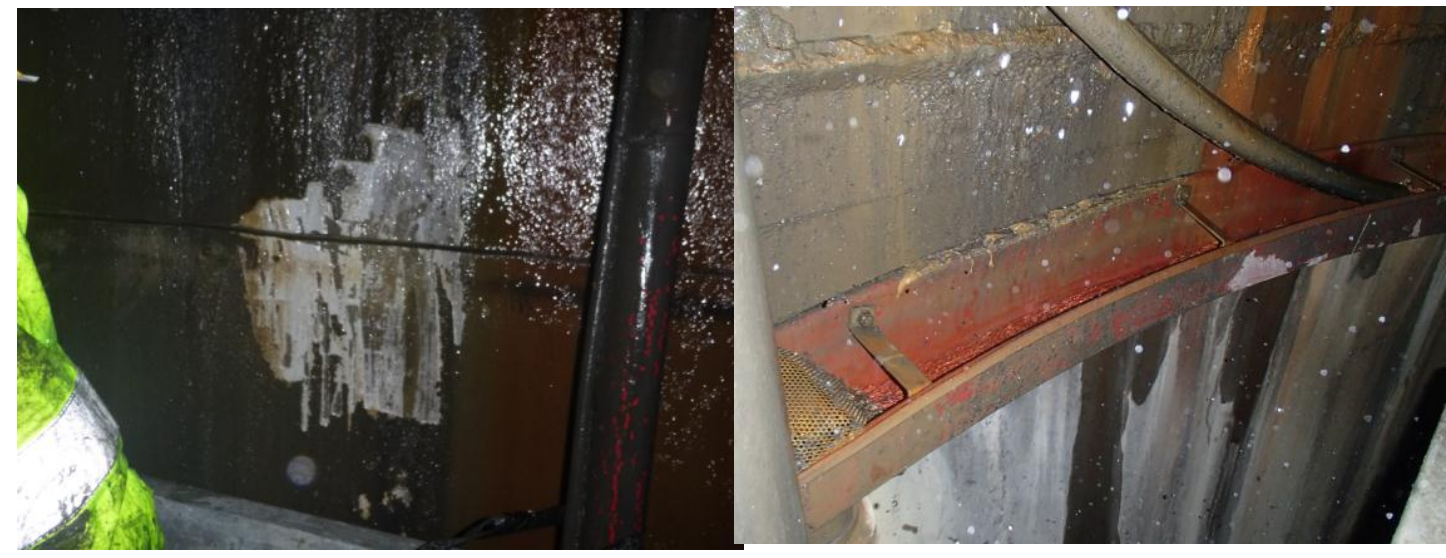

Gambar 7. Pemotongan dinding concrete shaft (kiri); Pemasangan pengait (brace) (kanan)

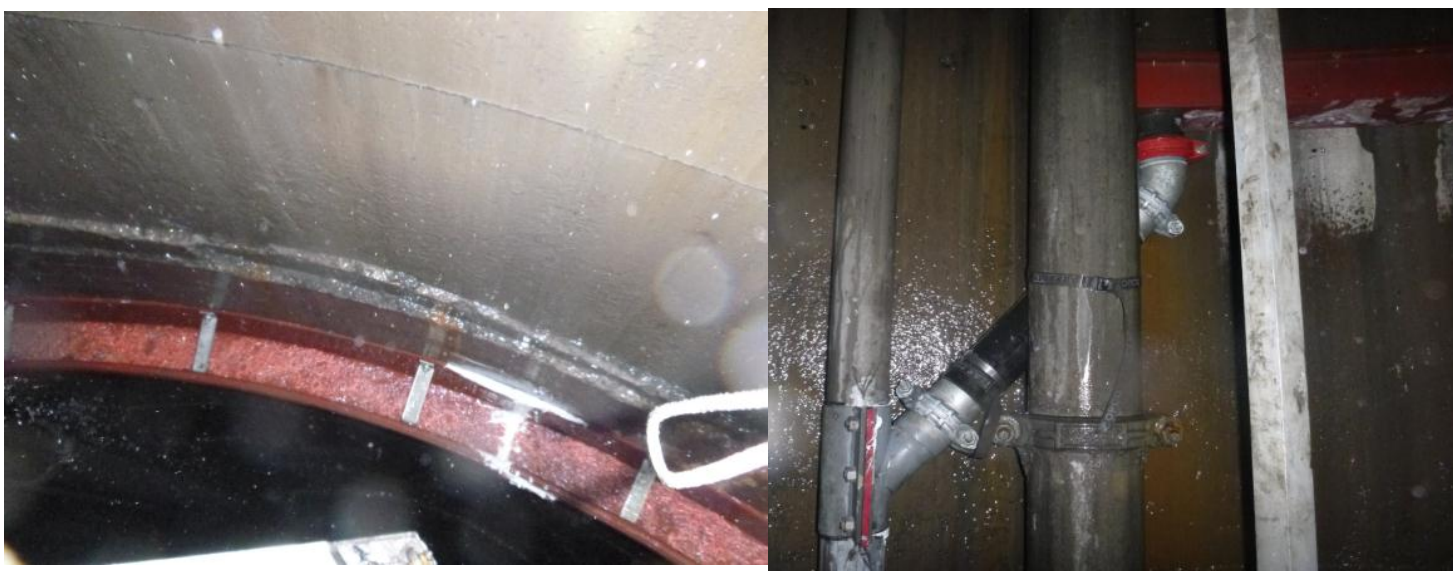

Gambar 8. Sambungan water ring (kiri); Sambungan selang (hose) dengan pipa services (kanan)

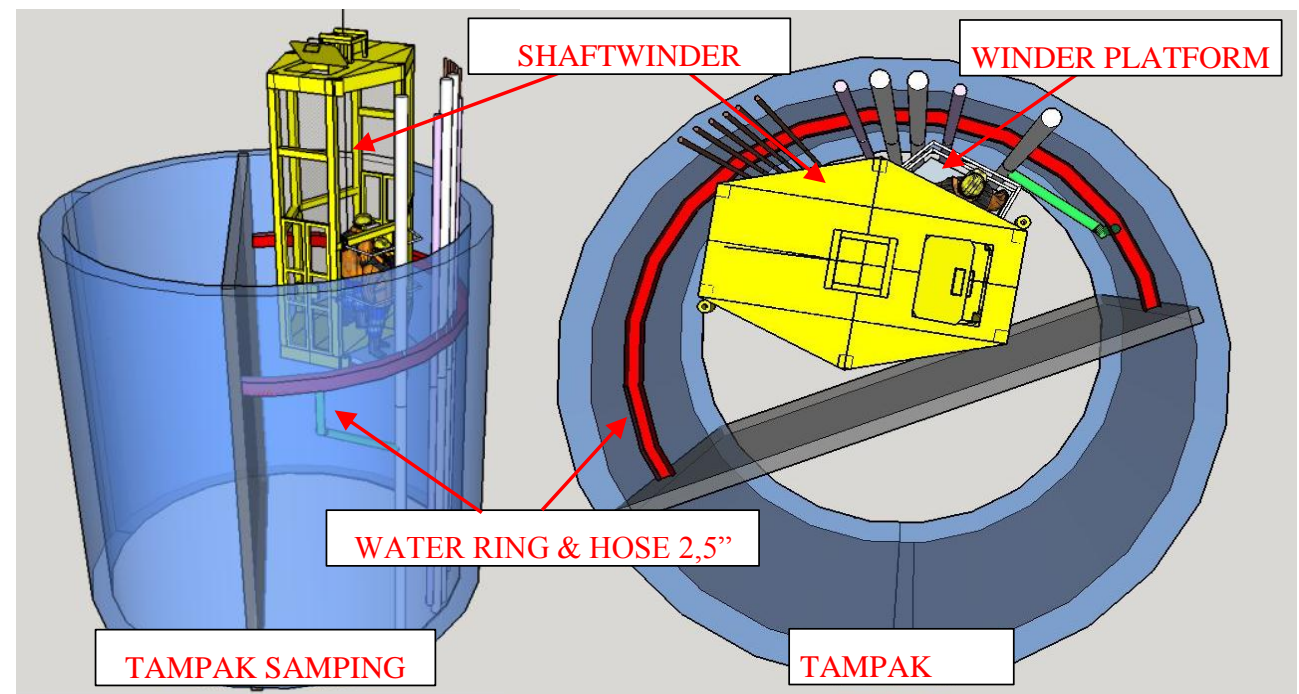


Gambar 9. Sketsa setelah pemasangan water ring menggunakan platform pada K2 shaft egress

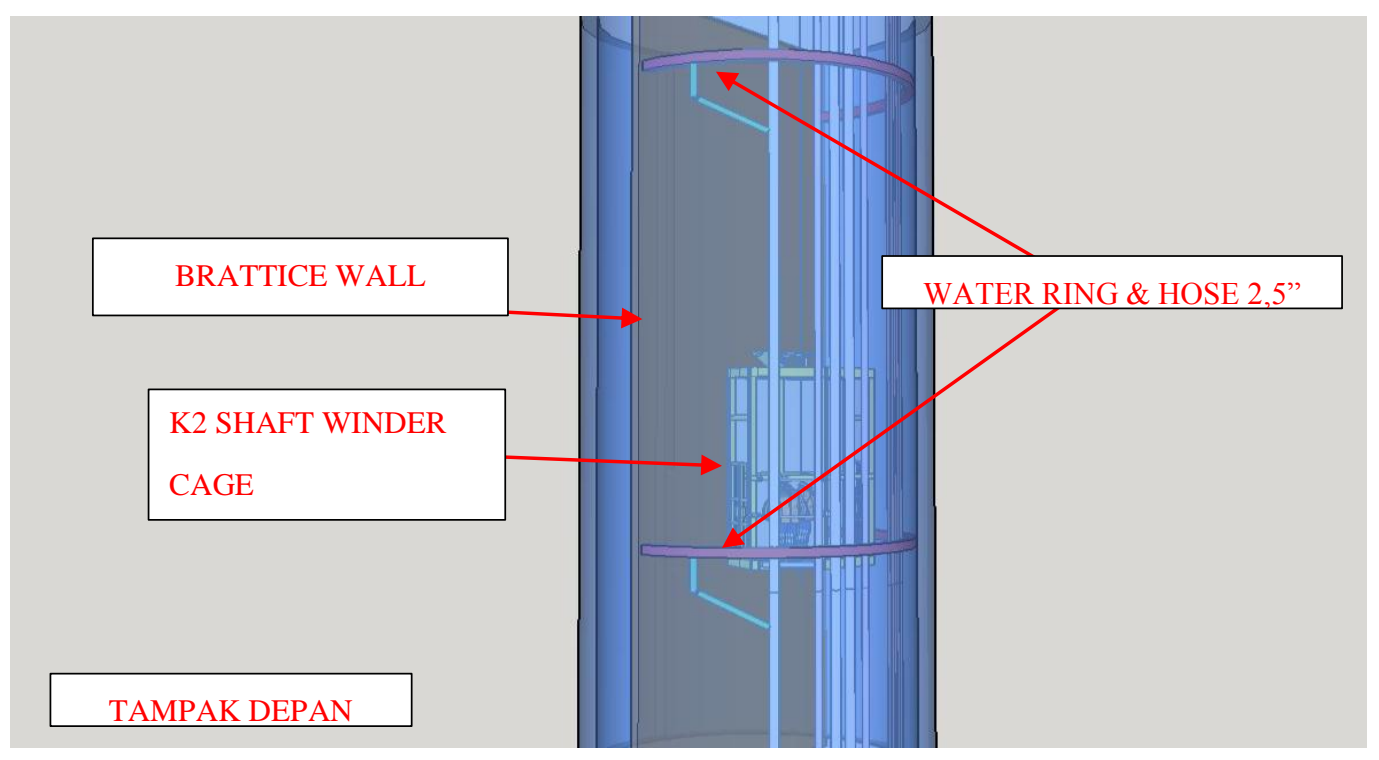

Gambar 10. Sketsa setelah pemasangan 2 set water ring menggunakan platform pada K2 shaft egress

\section{C.4. Modifikasi Winder Platform.}

Bekerja pada lokasi yang berada pada ketinggian and lubang terbuka shaft dimana posisi winder cage akan manuver tergolong pekerjaan beresiko tinggi (high risk) sehingga diperlukan engineering control dengan cara membuat winder platform dimaksudkan agar para pekerja (UG rehab crew) bisa menjangkau area terjauh pada saat setup dan pemasangan, dimana crew akan berada atau berdiri diluar posisi winder cage tetapi masih ditopang oleh platform. Setiap personel akan dilengkapi dengan perlengkapan keselamatan khusus pada saat bekerja berpotensi bahaya ketinggian. Jarak terjauh jangkauan winder ke dinding adalah $2 \mathrm{~m}$.

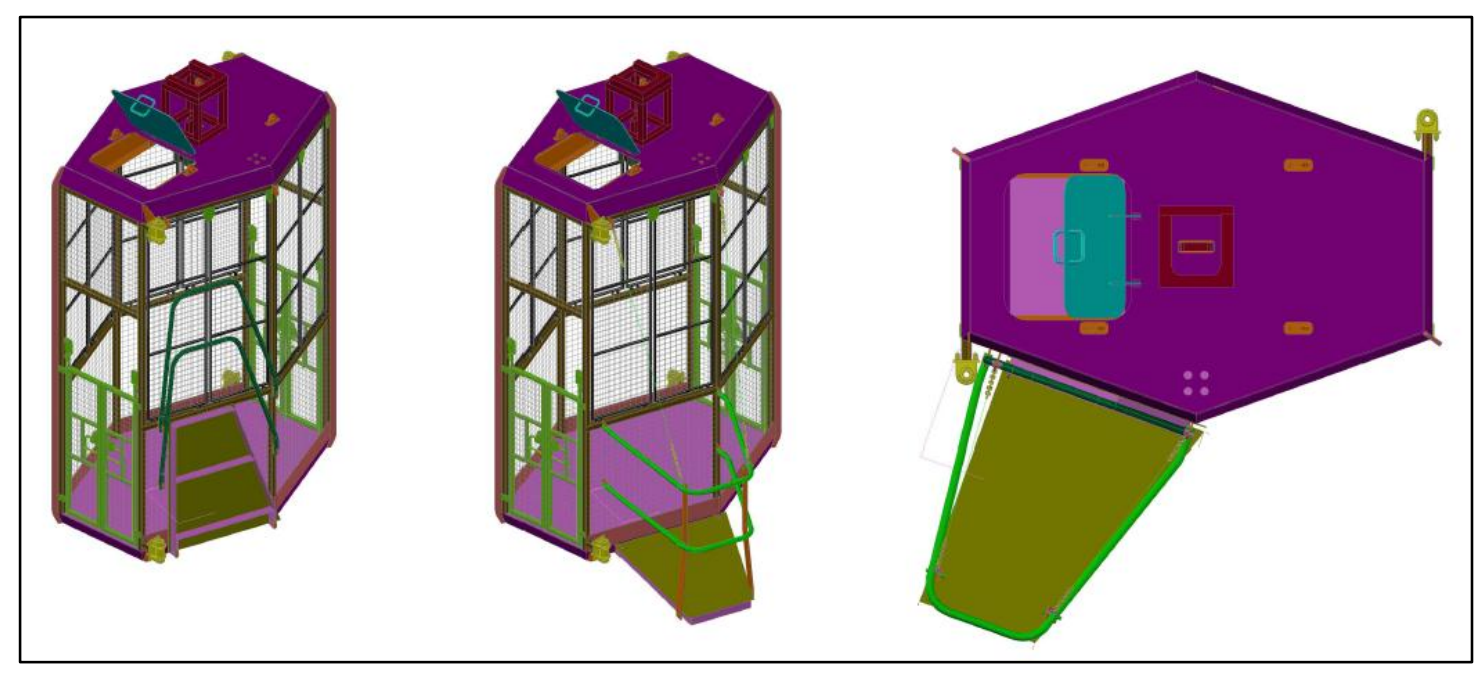

Gambar 11. Desain platform extension pada winder cage K2 shaft egress

D.5. Dewatering Monitoring dari K2 Shaft Water Ring menuju K2 Pump Station.

Air limpasan dari K2 shaft water ring sebanyak 8 l/s disalurkan melalui pipa services DN150 tersambung ke Flygt Pump $8 \mathrm{~kW}$ kemudian air dialirkan ke stasiun \#3 pompa KL sebagai sentral 
pompa dan tempat penampungan air untuk area development Kencana 2 (K2) dan Kencana Link (KL) sebelum disalurkan ke permukaan dengan metode multi stage pumping system.

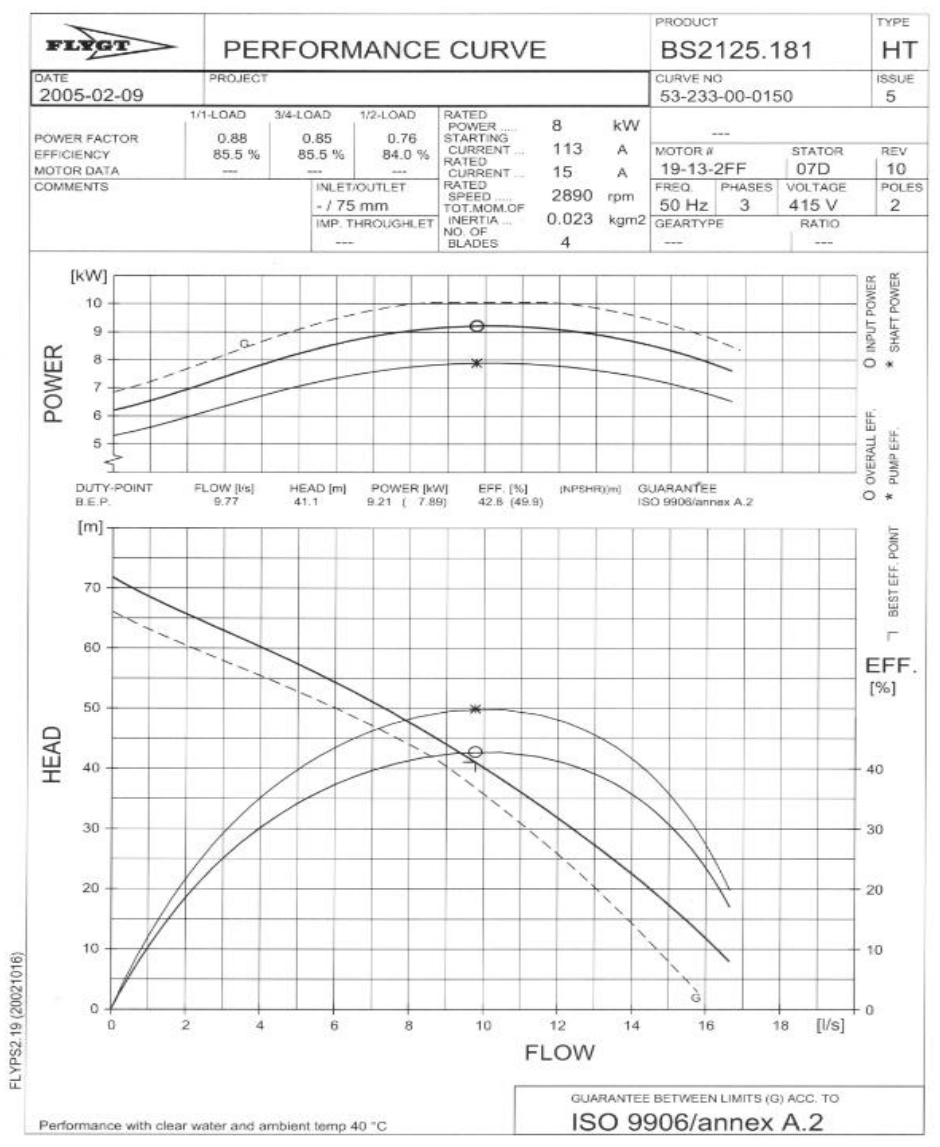

Gambar 12. Headpump dan spesifikasi pompa flygt 8kW dari K2 shaft egress

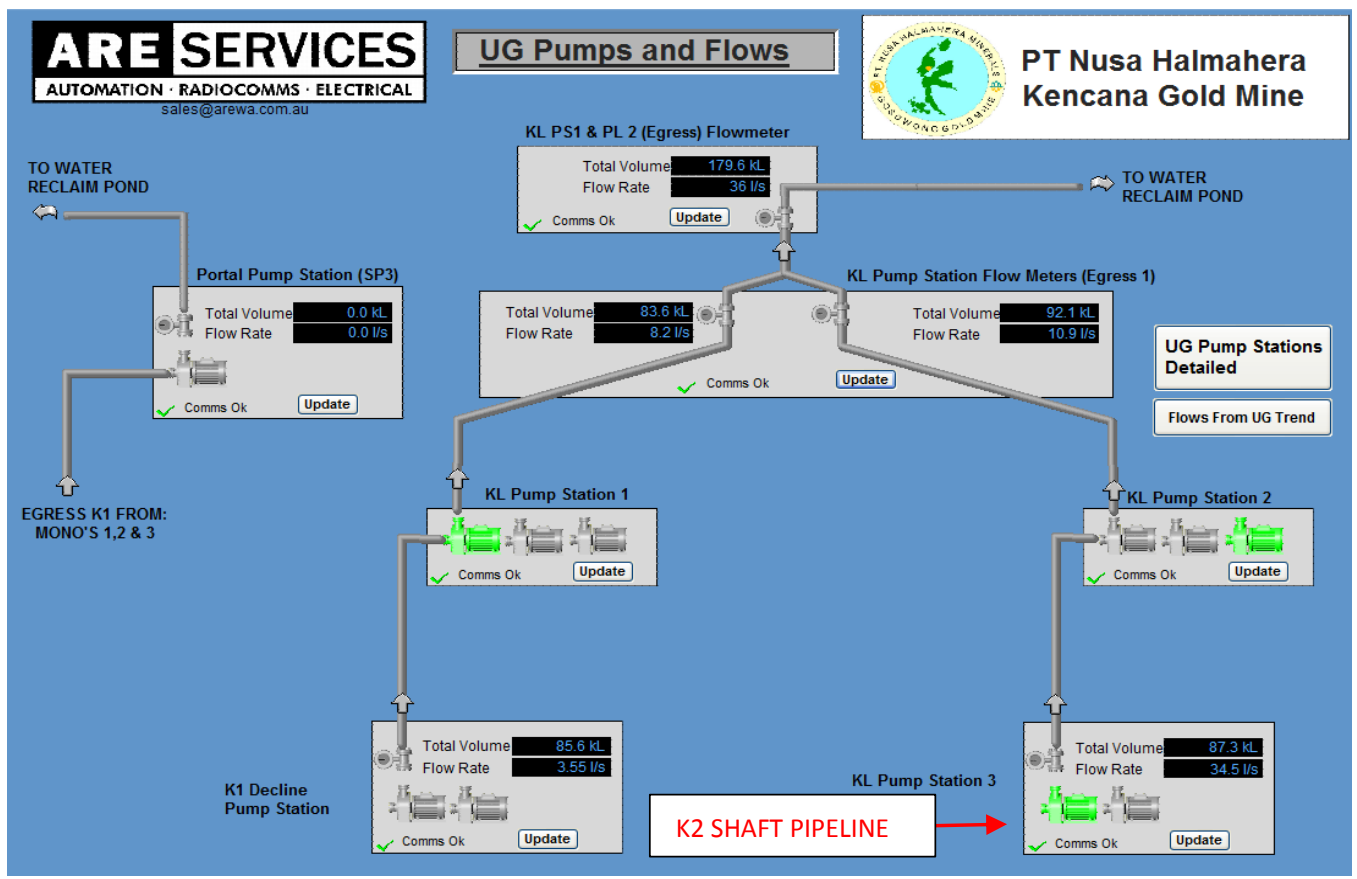

Gambar 13. Kencana UG sistem pemompaan (realtime monitoring) dari K2 Shaft Egress 


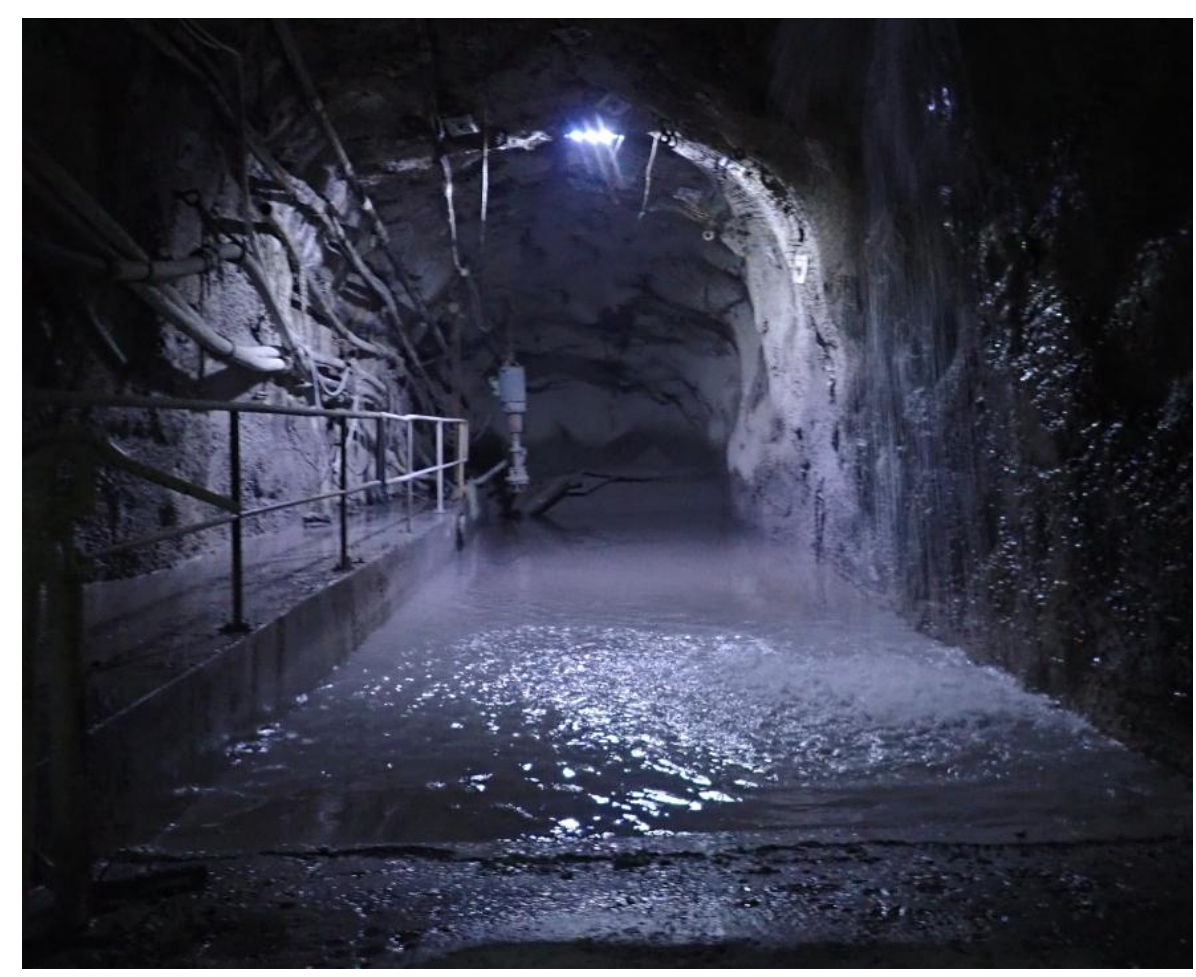

Gambar 14. Kolam penampungan air tambang UG di stasiun \#3 pompa KL

\section{D.6. Fokus Keselamatan Pada Bekerja di Ketinggian dan Lubang Terbuka}

Fokus keselamatan pada pekerjaan pemasangan water ring K2 shaft egress adalah resiko terjatuh saat bekerja di ketinggian (working at height) dan bekerja pada lubang terbuka (open hole working), termasuk juga bahaya terpapar udara bertekanan tinggi (jalur intake). Adanya faktor pertimbangan total beban untuk maximum kapasitas winder cage sehingga membatasi jumlah personil yang bekerja dalam winder, serta jumlah material dan peralatan kerja yang diangkut selama proses bekerja juga terbatas. Pekerja akan mengikuti prosedur komunikasi pada winder sesuai protokol radio komunikasi yang berlaku di site Gosowong. Langkah yang dilakukan untuk mengantisipasi resiko dan identifikasi bahaya utama dengan cara melakukan kritikal kontrol pada beberapa hal :

- Melakukan review dan verifikasi system pekerjaan (Audit terhadap winder hoist \& drum, hoist rope)

- Inspeksi mekanikal dan elektrikal terhadap winder hoist sebelum dipakai.

- Review dokumen lifting study dan standard work load (SWL).

- Review dokumen metode pengerjaan (work methodology) dan JSEA.

- Review engineering desain terhadap platform dan test beban di permukaan.

- Melengkapi peralatan APD pekerja untuk bekerja ketinggian (sala block, body harness \& lanyard).

- Melengkapi kompetensi pekerja yang bekerja di ketinggian.

- Protokol radio komunikasi khusus utk pengoperasian winder dan pekerjaan pemasangan water ring.

\section{KESIMPULAN}

- Pemasangan water ring dapat mengontrol rembesan air sehingga mengurangi kerusakan dinding concrete shaft dan unit winder cage akibat rembesan air tersebut. 
- Proses pemasangan water ring bisa laksanakan bersamaan pembersihan endapan calcite (scaling and clean up) sehingga mempengaruhi kualitas dan kekuatan dinding concrete shaft, dan mengurangi gangguan pengoperasian winder cage.

- Pemasangan water ring akan mempermudah pengelolaan air tambang (UG dewatering management) dimana rembesan air akan terkontrol pada saat pengaliran menuju level bawah stasiun pompa air K2 shaft. Kapasitas air limpasan dari K2 Shaft Egress 8 1/s, masih bisa terintegrasi ke sistem pemompaan yang sudah tersedia di stasiun\#03 pompa KL.

- Penentuan metode kerja dan pemilihan bahan/material yang sesuai dengan site condition akan meminimalisir resiko kerja berkaitan dengan keselamatan, dan mengurangi delay time saat rehabilitasi area shaft.

\section{UCAPAN TERIMA KASIH}

Penulis mengucapkan banyak terima kasih kepada Management PTNHM yang telah mengijinkan pembuatan tulisan dan menerbitkan, serta masukan dan input dari Shaft Project Engineer, dan dukungan dari UG Shaft \& Project Crew untuk semua pekerjaan project yang aman dan sesuai target.

\section{DAFTAR PUSTAKA}

Guppy, C. (2017): Hoisting System Physical Condition, PT Nusa Halmahera Minerals K2 Shaft Emergency EGRESS Hoisting System Inspection, K2 Shaft Audit Report, Wilshaw Consultant, 4-19.

Mine WaterMC. (2018): Sources of Data the hydrogeological studies and report, Numerical Groundwater Model, Mine WaterMC Pty Ltd, 3-7.

PT Nusa Halmahera Minerals. (2017): Ground Control Methods and Design, Ground Control Management Plan (GCMP) - Internal Document, 39-49.

Wahyudi, Abdi. (2009): Geotechnical Inspection Report, K2 Shaft Inspection Report, 1-2

Parson, Worley. (2012): Sinking Methodology, Shaft Construction Methodology, Worley Parson Consultant, 8-14. 
PROSIDING TPT XXVIII PERHAPI 2019 